\title{
Accumulation and Translocation of Toxic Heavy Metals in Winter Wheat (Triticum aestivum L.) Growing in Agricultural Soil of Zhengzhou, China
}

\author{
W.-X. Liu · J.-W. Liu · M.-Z. Wu • Y. Li • \\ Y. Zhao $\cdot$ S.-R. Li
}

Received: 20 December 2007/Accepted: 8 October 2008/Published online: 6 November 2008

(C) The Author(s) 2008. This article is published with open access at Springerlink.com

\begin{abstract}
A field experiment was conducted to study the accumulation of toxic heavy metals by winter wheat (Triticum aestivum L.) grown in the agricultural soil in the suburb of Zhengzhou City, China. The quantities of heavy metals $(\mathrm{Cd}, \mathrm{Cr}, \mathrm{Pb}, \mathrm{As}, \mathrm{Hg}$ ) were determined in different parts of wheat plant. The content of five toxic metals was found significantly higher in roots than in the aerial parts of wheat (stems and leaves, and grains). Additionally, wheat roots were enriched in $\mathrm{Cd}, \mathrm{Pb}$, and $\mathrm{Hg}$ from the soil, while $\mathrm{Cr}$ and As were hardly taken up by the roots. On the other hand, the winter wheat transported five toxic heavy metals very weakly from root to grain in the various irrigation regions.
\end{abstract}

Keywords Bioconcentration factor - Heavy metal uptake · Translocation · Winter wheat (Triticum aestivum L.)

Toxic heavy metals enter the food chain due to uptake and accumulation by crop, posing a potential threat to human health. There are various reports on the effect of different stress conditions on the crop, paddy and natural soils (Kirkham 1983; Petruzzelli et al. 1987; Liu et al. 2005; Wong et al. 2002). Heavy metals, such as Cr, Cd, Pb, As and $\mathrm{Hg}$ are often cited as primary contaminants of concern,

W.-X. Liu ( $\bowtie) \cdot$ M.-Z. Wu · Y. Li · Y. Zhao · S.-R. Li Department of Environmental Sciences, Henan Agricultural University, Zhengzhou 450002, People's Republic of China e-mail: hjxliuwenxia@163.com

J.-W. Liu

Environmental Protection Bureau of Henan Province,

Zhengzhou 450007, People's Republic of China and the possibility of synergistic effects of two or more metals may be of considerable importance at some sites contaminated with heavy metals (Nan et al. 2002). These metals can be transferred and concentrated into plant tissues from the soil, and brought about significant reductions in both plant growth and grain yield of wheat (Athar and Ahmad 2002; Öncel et al. 2000). They can be toxic to photosynthetic activity, chlorophyll synthesis and antioxidant enzymes (Murzaeva 2004; Ouzounidou et al. 1997; Panda et al. 2003).

Every metal and plant interacts in a specific way, which depends on several factors such as soil type, plant, growth conditions and the presence of other ions. Metal uptake by grains was directly related to the applied heavy metal with greater concentrations of metals found in cases where metals were added separately rather than in combinations (Athar and Ahmad 2002). Different tillage systems, continuous grass and agricultural crops rotation affect the uptake and distribution of heavy metals (Al-Najar et al. 2005; Lavado et al. 2001). Liu et al. (2006, 2007) reported that rice plant and vegetables accumulated heavy metals from the agricultural soil under actual natural condition. However, few studies have been carried out on the fully grown plant of wheat raised on the agricultural soil. Therefore, a field experiment was carried out to investigate accumulation and translocation of toxic heavy metal by winter wheat grown in the agricultural soil under real field condition. This has important implication in the understanding of heavy metal contamination through the food chain.

\section{Materials and Methods}

The crop chosen for study was winter wheat (Triticum aestivum L.) which was the main crop cultivated in the area, and 
its growing period was about 210 days (from November to May of the following year) in the suburb of Zhengzhou city, Henan Province, China $\left(34^{\circ} 42^{\prime} \mathrm{N} ; 113^{\circ} 45^{\prime} \mathrm{E}\right.$; altitude $110.4 \mathrm{~m}$ ). The area has a warm spring continental weather with an annual average temperature and rainfall of $14.3^{\circ} \mathrm{C}$ and $640.5 \mathrm{~mm}$, respectively. Wheat plants were sampled during maturity at eight sites in May 1998, which were divided into three districts: municipal sewage irrigation region (MSIR) (Chengang, Xuzhuang, and Jiagang), Yellow River irrigation region (YRIR) (Zhaolanzhuang, and Jingshuicun), and groundwater irrigation region (GWIR) (Xincun, Ershilipu and Huayuankouxiliuhuangcun). Wheat plants were selected with five points at each site, and the corresponding soils (at $0-20 \mathrm{~cm}$ in depth) were also collected. Sampled plants were separated into roots, aboveground material (stems and leaves), and grains, and then rinsed with deionized water, dried at $65^{\circ} \mathrm{C}$ for $48 \mathrm{~h}$, grounded with an agate mill, and homogenized.

Metals $\mathrm{As}, \mathrm{Hg}, \mathrm{Cd}, \mathrm{Pb}$ and $\mathrm{Cr}$ were determined according to previously described methods (Liu et al. 2007). A microwave assisted digestion procedure was used. About $0.5-3 \mathrm{~g}$ of homogenized samples was digested under pressure in Teflon vessels with $4 \mathrm{~mL}$ of nitric acid and $1.5 \mathrm{~mL}$ of hydrogen peroxide. Samples with a low aqueous content were ashed at $450^{\circ} \mathrm{C}$ in a furnace. On completion of the digestion and after adequate cooling, solutions were filtered and made up to $50 \mathrm{~mL}$ with $1 \%$ nitric acid.

Metals $\mathrm{Cr}, \mathrm{Cd}$, and $\mathrm{Pb}$ contents were analyzed by flame atomic absorption spectrometry (FAAS, Hitachi Z-8000, Hitachi Ltd., Tokyo, Japan), whereas concentrations of $\mathrm{Hg}$ and As were determined using cold-vapor atomic absorption spectrometry (CV-AAS) with a hydride generation VA-90 model (TongJi University, China) and sodium borohydride as the reductant. All reagents were supra-pure and high-purity water was employed throughout. A sample of standard reference material (NIST SRM 2709), a blank, and a determination in duplicate were included for assurance of analytical accuracy. The analytical results showed no signs of contamination and that the precision and bias of the analysis were generally $<10 \%$ for metals. The recovery rates for heavy metals in SMR were around 85\%-105\%. Data analyses were carried out with statistical package SPSS 11.0. The statistical significance level was defined at $p<0.05$.

\section{Results and Discussion}

The crops were wheat-rice in continuous sequence at the same location. According to the previous published data, the soils were uncontaminated with heavy metals (Liu et al. 2007). The average concentrations in agricultural soils ranged $0.11-0.14 \mathrm{mg} \mathrm{kg}^{-1}$ for $\mathrm{Cd}, \quad 57.54$ $65.67 \mathrm{mg} \mathrm{kg}^{-1}$ for $\mathrm{Cr}, 14.42-19.28 \mathrm{mg} \mathrm{kg}^{-1}$ for $\mathrm{Pb}$, $0.041-0.10 \mathrm{mg} \mathrm{kg}^{-1}$ for $\mathrm{Hg}$, and $6.10-6.97 \mathrm{mg} \mathrm{kg}^{-1}$ for As, respectively. Concentrations of $\mathrm{Cd}, \mathrm{Cr}, \mathrm{Pb}$ and $\mathrm{As}$ in soils didn't vary significantly among the different irrigation regions, while content of $\mathrm{Hg}$ was higher in MSIR and YRIR than GWIR. Contents of $\mathrm{Cd}$ and $\mathrm{Pb}$ in the studied soil were markedly lower than that of $\mathrm{Cd}\left(2.82 \mathrm{mg} \mathrm{kg}^{-1}\right)$ and $\mathrm{Pb}\left(74.88 \mathrm{mg} \mathrm{kg}^{-1}\right)$ in the croplands near the nonferrous metals mining and smelting base of Baiyin city, Gansu province, P.R. China (Nan et al. 2002), respectively.

Heavy metals concentrations in different parts of wheat plants are presented in Table 1. In all cases, higher concentrations of studied heavy metals were found in the roots, in comparison with the aboveground material and grains. Average $\mathrm{Cd}$ values in wheat roots were $3.87,1.96$, and $1.44 \mathrm{mg} \mathrm{kg}^{-1}$ for MSIR, YRIR, and GWIR, respectively. $\mathrm{Cd}$ concentrations of roots showed some differences in both cereals (winter wheat and rice) (Liu et al. 2007). Average $\mathrm{Cd}$ concentration in wheat grains was 0.018 $0.023 \mathrm{mg} \mathrm{kg}^{-1}$ between various irrigation regions. No significant differences were found between MSIR and YRIR, and GWIR for Cd concentration of grain, but there were significant differences between MSIR and YRIR $(p<0.05)$, between MSIR and GWIR $(p<0.01)$ for $\mathrm{Cd}$ concentration of root. This indicated that different riverhead affects the uptake of $\mathrm{Cd}$ in the wheat root. On the other hand, $\mathrm{Cd}$ concentration of grain was very lower than Cd content $\left(0.23 \mathrm{mg} \mathrm{kg}^{-1}\right)$ of spring wheat grain grown in contaminated soil (Nan et al. 2002). The increment of total soil content of $\mathrm{Cd}$ could enhance grain $\mathrm{Cd}$ accumulation.

The content of $\mathrm{Cr}$ in the wheat roots was 3.36$5.97 \mathrm{mg} \mathrm{kg}^{-1}$, which was slightly higher than that in rice roots at the same location (Liu et al. 2007). Among the different parts of the wheat crop, the lowest value of $\mathrm{Cr}$ was observed for the grain $\left(0.12-0.18 \mathrm{mg} \mathrm{kg}^{-1}\right)$. This was in accordance with the findings of Liu et al. (2007), who reported the lowest value of $\mathrm{Cr}$ in the rice grain among root, straw and grain.

The arsenic average level varied from 1.76 to $3.59 \mathrm{mg} \mathrm{kg}^{-1}$ in roots, from 0.34 to $0.91 \mathrm{mg} \mathrm{kg}^{-1}$ in stems and leaves, and from 0.11 to $0.16 \mathrm{mg} \mathrm{kg}^{-1}$ in wheat grains. A gradual increase of the contents could be observed in the wheat plant, from grain, aboveground material to root. The significant differences were found in every irrigation region between root, and stem and leaf, and grain $(p<0.01)$, whereas no significant differences were found between various irrigation regions for As content of root. The concentration in the winter wheat grain was very much lower than in wheat grain $\left(0.7 \mathrm{mg} \mathrm{kg}^{-1}\right)$ cultivated agricultural area of West Bengal Delta Plain, irrigated with As rich groundwater (Norra et al. 2005). The arsenic concentrations in stems and leaves, and grains were similar in both 
Table 1 Heavy metal concentrations in wheat plants $\left(\mathrm{mg} \mathrm{kg}^{-1} \mathrm{dw}\right)$

\begin{tabular}{|c|c|c|c|c|c|c|}
\hline \multirow[t]{2}{*}{ Components } & \multicolumn{2}{|l|}{ MSIR (n = 15) } & \multicolumn{2}{|l|}{ YRIR (n = 10) } & \multicolumn{2}{|l|}{ GWIR (n = 15) } \\
\hline & Range & Mean $\pm \mathrm{SD}$ & Range & Mean \pm SD & Range & Mean \pm SD \\
\hline \multicolumn{7}{|l|}{$\mathrm{Cd}$} \\
\hline Roots & $2.63-4.83$ & $3.87 \pm 1.13$ & $1.43-2.49$ & $1.96 \pm 0.54$ & $1.40-1.47$ & $1.44 \pm 0.038$ \\
\hline Leaves and stems & $1.27-1.90$ & $1.46 \pm 0.38$ & $0.70-1.19$ & $0.89 \pm 0.26$ & $0.78-1.25$ & $0.94 \pm 0.27$ \\
\hline Grains & $0.015-0.025$ & $0.023 \pm 0.011$ & $0.015-0.024$ & $0.019 \pm 0.016$ & $0.016-0.019$ & $0.018 \pm 0.002$ \\
\hline \multicolumn{7}{|l|}{$\mathrm{Cr}$} \\
\hline Roots & $2.55-8.07$ & $5.50 \pm 2.78$ & $4.16-6.77$ & $5.97 \pm 1.57$ & $2.92-3.73$ & $3.36 \pm 0.41$ \\
\hline Leaves and stems & $1.41-1.95$ & $1.79 \pm 0.33$ & $1.45-1.81$ & $1.66 \pm 0.19$ & $1.21-1.77$ & $1.51 \pm 0.28$ \\
\hline Grains & $0.16-0.23$ & $0.18 \pm 0.042$ & $0.12-0.21$ & $0.16 \pm 0.12$ & $0.087-0.18$ & $0.12 \pm 0.052$ \\
\hline \multicolumn{7}{|l|}{$\mathrm{Pb}$} \\
\hline Roots & $18.49-30.83$ & $24.25 \pm 6.21$ & $21.55-22.76$ & $22.16 \pm 0.61$ & $16.31-21.43$ & $18.87 \pm 2.56$ \\
\hline Leaves and stems & $11.45-25.39$ & $18.90 \pm 7.02$ & $14.42-18.49$ & $17.13 \pm 2.35$ & $11.77-17.28$ & $14.91 \pm 2.83$ \\
\hline Grains & $0.12-1.43$ & $0.99 \pm 0.61$ & $0.14-1.88$ & $1.01 \pm 0.36$ & $0.12-1.66$ & $0.99 \pm 0.40$ \\
\hline \multicolumn{7}{|l|}{$\mathrm{Hg}$} \\
\hline Roots & $0.084-0.19$ & $0.12 \pm 0.061$ & $0.092-0.095$ & $0.093 \pm 0.016$ & $0.075-0.090$ & $0.085 \pm 0.0087$ \\
\hline Leaves and stems & $0.042-0.061$ & $0.054 \pm 0.010$ & $0.034-0.052$ & $0.043 \pm 0.0093$ & $0.040-0.048$ & $0.045 \pm 0.0044$ \\
\hline Grains & $0.0024-0.0037$ & $0.0029 \pm 0.0008$ & $0.0026-0.0028$ & $0.0027 \pm 0.0001$ & $0.0021-0.0028$ & $0.0024 \pm 0.0004$ \\
\hline \multicolumn{7}{|l|}{ As } \\
\hline Roots & $2.65-5.95$ & $3.59 \pm 2.06$ & $1.58-1.95$ & $1.76 \pm 0.19$ & $1.67-4.31$ & $2.99 \pm 1.32$ \\
\hline Leaves and stems & $0.48-1.24$ & $0.83 \pm 0.38$ & $0.17-0.52$ & $0.34 \pm 0.18$ & $0.51-1.30$ & $0.91 \pm 0.39$ \\
\hline Grains & $0.10-0.12$ & $0.11 \pm 0.02$ & $0.070-0.20$ & $0.14 \pm 0.14$ & $0.12-0.21$ & $0.16 \pm 0.046$ \\
\hline
\end{tabular}

cereals (winter wheat and rice). Conversely, the As content was considerably lower in wheat root than rice root (20.87$\left.23.89 \mathrm{mg} \mathrm{kg}^{-1}\right)(p<0.01)$ (Liu et al. 2007). The higher As contents measured in the roots are due to an Fe-rich mineral plaque which coat the rice roots (Norra et al. 2005).

Ranges of $\mathrm{Hg}$ concentration were $0.085-0.12 \mathrm{mg} \mathrm{kg}^{-1}$ for root, $0.043-0.054 \mathrm{mg} \mathrm{kg}^{-1}$ for stem and leaf, and $0.0024-0.0029 \mathrm{mg} \mathrm{kg}^{-1}$ for grain among the various irrigation regions. No significant differences were found between MSIR and YRIR, and GWIR for $\mathrm{Hg}$ concentration of root. Compared with rice, $\mathrm{Hg}$ concentration of grain was significantly lower in wheat $(p<0.01)$. In addition, the concentrations of $\mathrm{Cd}, \mathrm{Cr}$, As and $\mathrm{Hg}$ in the edible grain were well below the Chinese national food guideline limit. Therefore, the wheat grain was uncontaminated with $\mathrm{Cd}$, $\mathrm{Cr}$, As and $\mathrm{Hg}$.

Average values of $\mathrm{Pb}$ in wheat roots were 18.81$24.25 \mathrm{mg} \mathrm{kg}^{-1}$ in different irrigation regions, which no significant differences were found between MSIR and YRIR, and GWIR. Among root, stem and leaf, and grain, the lowest value of $\mathrm{Pb}$ was also observed for the grain (0.99-1.01 mg kg-1). Winter wheat showed higher concentrations of $\mathrm{Pb}$ in each part than the rice rotation with winter wheat, respectively (Liu et al. 2007). This indicated that its uptake and accumulation in winter wheat were higher than in rice. Moreover, concentrations of $\mathrm{Pb}$ in the wheat grain approach the Chinese national food guideline limit $\left(1.0 \mathrm{mg} \mathrm{kg}^{-1}\right)$. Therefore, it is worth noticing $\mathrm{Pb}$ contamination in the wheat grain. In general terms, the contents of five toxic metals were higher in roots than in the aerial parts for both crops (wheat and rice) cultivated in the agricultural soil, indicating that the roots act as barrier for metal translocation and protect the edible parts from toxic heavy metal contamination.

The bioconcentration factor (BCF) was calculated as the ratio of the content of heavy metal in the wheat plant to that in the soil. Figures 1, 2 show the BCF values for $\mathrm{Cr}$, As, $\mathrm{Pb}, \mathrm{Cd}$, and $\mathrm{Hg}$ in wheat plant. When a $\mathrm{BCF} \leq 1$, it indicates that the plant can only absorb but not accumulate heavy metals; when a $\mathrm{BCF}>1$, it shows that plant can accumulate metals. Chromium $\mathrm{BCF}$ value range for wheat in different irrigation regions was 0.058-0.094 (root), 0.026-0.030 (stem and leaf), and 0.0021-0.0030 (grain). There are nearly the same trend of $\mathrm{Cr}$ uptake between winter wheat and rice (Liu et al. 2007). Additionally, $\mathrm{Cr}$ uptake by wheat and rice plants was not significantly different among the various irrigation regions. Therefore, it can be concluded that $\mathrm{Cr}$ bioavailability was very low in the agriculture soil for the both crops.

$\mathrm{BCF}$ value of As ranged from 0.29 to 0.53 (root), from 0.057 to 0.13 (stem and leaf), from 0.017 to 0.024 (grain), and all values were below 1.0. The winter wheat uptake of As was not significantly different among the various 

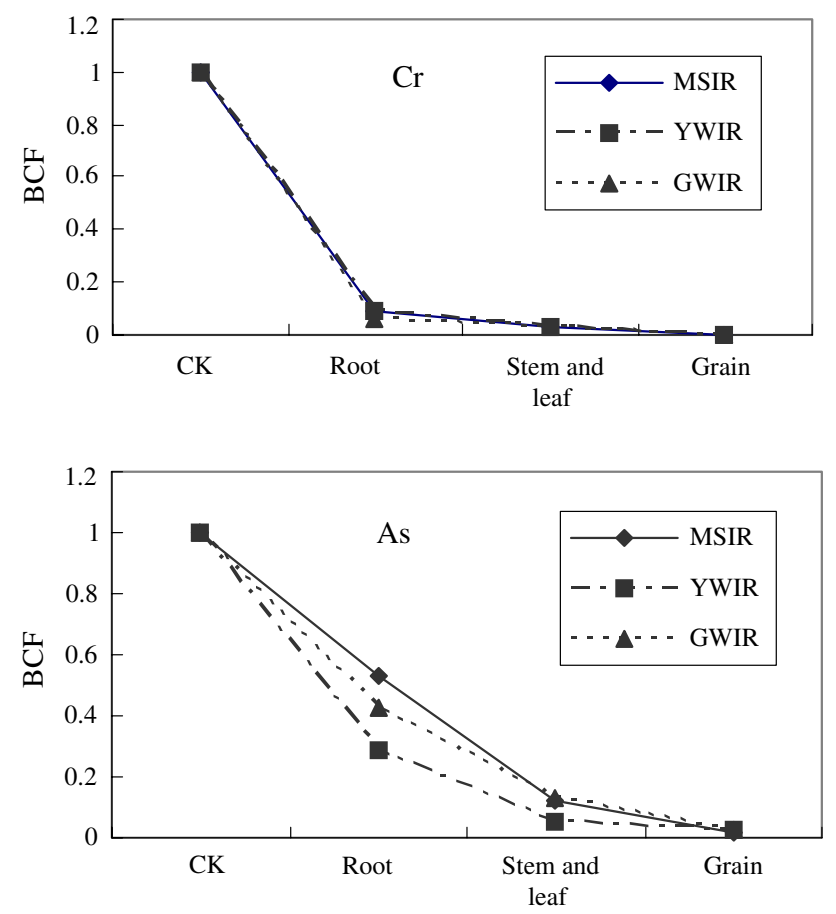

Fig. 1 BCF values of $\mathrm{Cr}$ and As of winter wheat from the suburb of Zhengzhou, China

irrigation regions. Noteworthy wheat root has lower capacity to uptake As compared with rice root (Liu et al. 2007). These differences between winter wheat and rice depend on the individual plant species and genotype.

$\mathrm{BCF}$ range of $\mathrm{Pb}$ in the winter wheat was 1.15-1.32, 0.89-1.03, and 0.053-0.069 for root, stem and leaf, and grain, respectively. $\mathrm{BCF}$ value of $\mathrm{Pb}$ in each part was higher in wheat than rice plant $(0.27-0.43$ for root, 0.10 0.14 for straw, and $0.011-0.029$ for grain). The rhizosphere changes of various crops affect $\mathrm{Pb}$ bioavailability. $\mathrm{BCF}$ value of $\mathrm{Pb}$ in the winter wheat grain is higher than in the grain of spring wheat grown in contaminated soils, where $\mathrm{Pb}$ content of soil is 3.32 times higher than in the studied agricultural soil (Nan et al. 2002). This indicates that the uptake of $\mathrm{Pb}$ is not only related to the plant species, but to the total concentration in the soil.

$\mathrm{BCF}$ range of $\mathrm{Cd}$ in winter wheat was 13.05-27.6 for root, 7.6-10.42 for stem and leaf, and 0.16-0.17 for grain. $\mathrm{BCF}$ value of $\mathrm{Cd}$ for the grain of winter wheat is higher than the spring wheat grown in contaminated soils (Nan et al. 2002), where Cd content of soil is up to 22.5 times higher than the agricultural soil. Additionally, the Cd uptake by wheat roots has the relation: MSIR $>$ YRIR $>$ GWIR. It is possible that the organic contaminant in municipal sewage enhanced Cd uptake. Zarcinas et al. (2004) also reported that Cd uptake was strongly correlated with organic matter. Winter wheat and rice root accumulated high quantities of $\mathrm{Cd}^{2+}$ when grown in non-pollution areas as in a medium
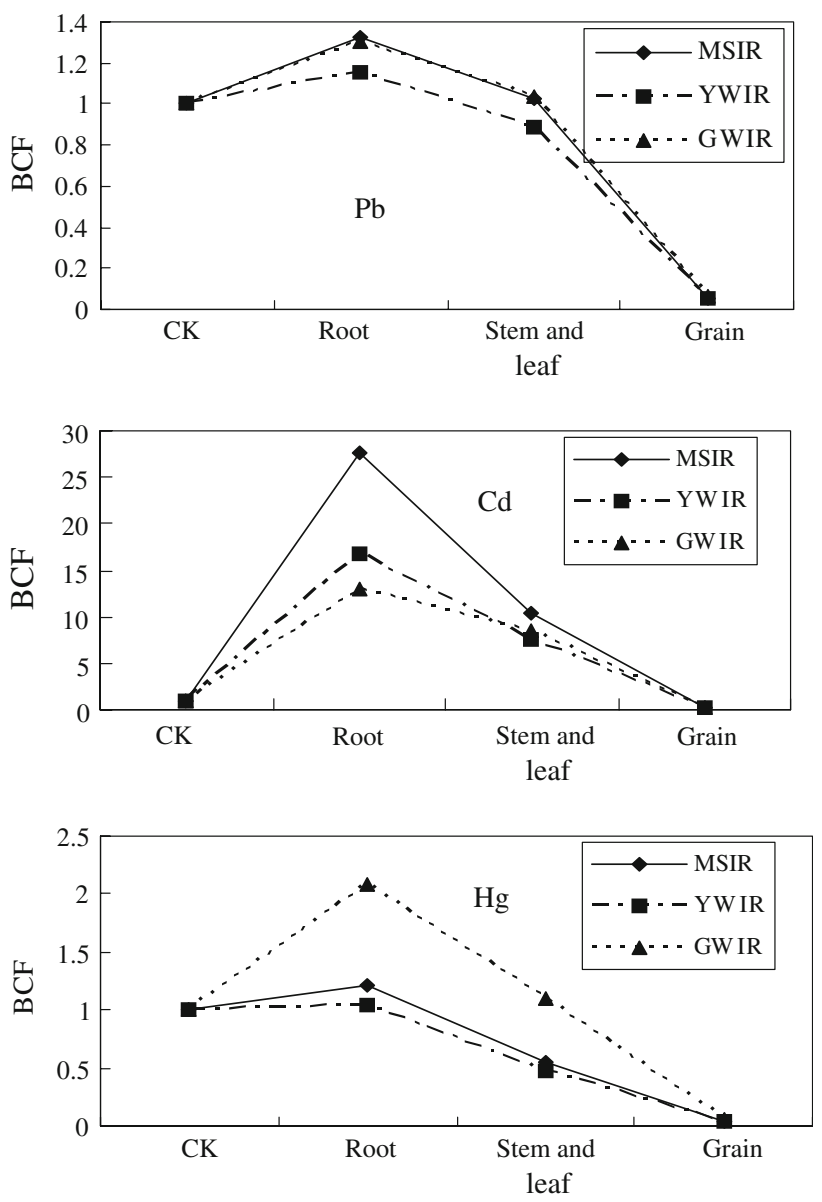

Fig. $2 \mathrm{BCF}$ values of $\mathrm{Pb}, \mathrm{Cd}$ and $\mathrm{Hg}$ of wheat plants from the suburb of Zhengzhou, China

containing this metal (Rubio et al. 1994; Liu et al. 2007). In response to $\mathrm{Cd}$, higher plants synthesize sulphur-rich peptides, phytochelatins (PCs). PC-heavy metal complexes have been reported to accumulate in the vacuole. Retention of $\mathrm{Cd}$ in the root cell vacuoles might influence the symplastic radial $\mathrm{Cd}$ transport to the xylem and further transport to the shoot (Stolt et al. 2003).

$\mathrm{BCF}$ range of $\mathrm{Hg}$ was 1.03-2.09, 0.48-1.10, and 0.0290.059 for root, stem and leaf, and grain in winter wheat, respectively. Some difference for $\mathrm{Hg}$ uptake was observed in various irrigation regions. The mechanism has not been elucidated yet.

In conclusion, wheat plants showed the greatest accumulation of $\mathrm{Cd}, \mathrm{Hg}$, and $\mathrm{Pb}$ in the roots, though there are different in various irrigation regions. Nevertheless, As and $\mathrm{Cr}$ were hardly taken up by the wheat root. The heavy metal uptake by winter wheat roots was in the following order: $\mathrm{Cd}>\mathrm{Hg}>\mathrm{Pb}>\mathrm{As}>\mathrm{Cr}$, in contrast to rice root, where it was $\mathrm{Cd}>\mathrm{As}>\mathrm{Hg}>\mathrm{Pb}>\mathrm{Cr}$ (Liu et al. 2007). Thus, passage from ex planta to in planta regions of the soil-plant system is dependent not only on properties of the plant, but also on those of the heavy metal pollutant. 


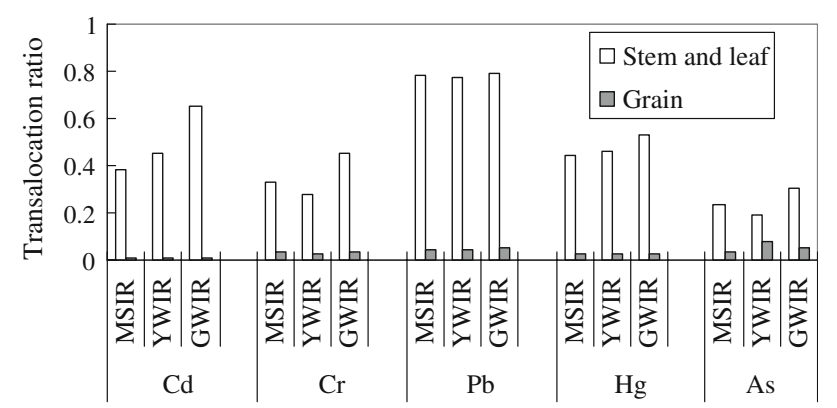

Fig. 3 Translocation ratios of heavy metals in the stem and leaf, and grains of wheat plant

Further, translocation ratios $\left(\mathrm{HM}_{\text {stem }}\right.$ and leaf or grain/ $\mathrm{HM}_{\text {root}}$ ), from root to stem and leaf or grain, were calculated for each heavy metal. Figure 3 showed translocation ratios of $\mathrm{Cd}, \mathrm{Hg}, \mathrm{As}, \mathrm{Cr}$, and $\mathrm{Pb}$ in winter wheat in various irrigation regions, and all values were below 1 . Translocation ratio of stem and leaf was more than that of grain for each heavy metal in the different irrigation. Moreover, the translocation factor from stem and leaf to grain $\left(\mathrm{HM}_{\text {grain }} /\right.$ $\mathrm{HM}_{\text {stem and leaf }}$ ) was found smaller than that of root to stem and leaf $\left(\mathrm{HM}_{\text {stem and leaf }} / \mathrm{HM}_{\text {root }}\right)$ of wheat plant except for arsenic in the YWIR. This finding is in good agreement with the results obtained in wheat grown in soil amended with industrial sludge by Bose and Bhattacharyya (2008). For five toxic heavy metals, absorption of wheat plant had the relation: Root $>$ Straw $\gg$ Grain. It is important to note that five toxic heavy metals were transported very weakly into the grain of winter wheat. Additionally, the results revealed that winter wheat transported As very weakly into the stem and leaf, whereas $\mathrm{Pb}$ was transported most easily into the stem and leaf among studied heavy metals. Compared with rice plant, winter wheat transported $\mathrm{Hg}$ very weakly from root into grain, but arsenic was transported more easily into stem and leaf, and grain of the winter wheat than rice (Liu et al. 2007). The five heavy metals examined in the research have different chemical properties and consequently each metal has peculiar accumulation and translocation capacity.

Acknowledgments This study is supported by innovation foundation of Forestry and Horticulture College, Henan Agricultural University (LYKY200710).

Open Access This article is distributed under the terms of the Creative Commons Attribution Noncommercial License which permits any noncommercial use, distribution, and reproduction in any medium, provided the original author(s) and source are credited.

\section{References}

Al-Najar H, Schulz R, Breuer J, Roemheld V (2005) Effect of cropping system on the mobility and uptake of $\mathrm{Cd}$ and $\mathrm{Zn}$. Environ Chem Lett 3:13-17. doi:10.1007/s10311-005-0105-z

Athar R, Ahmad M (2002) Heavy metal toxicity: effect on plant growth and metal uptake by wheat, and on free living azotobacter. Water Air Soil Pollut 138:165-180. doi:10.1023/ A: 1015594815016

Bose S, Bhattacharyya AK (2008) Heavy metal accumulation in wheat plant grown in soil amended with industrial sludge. Chemosphere 70:1264-1272. doi:10.1016/j.chemosphere.2007.07.062

Kirkham MB (1983) Elemental content of soil, sorghum and wheat on sludge-injected agricultural land. Agri Ecosystems Environ 9:281-292. doi:10.1016/0167-8809(83)90102-0

Lavado RS, Porcelli CA, Alvarez R (2001) Nutrient and heavy metal concentration and distribution in corn, soybean and wheat as affected by different tillage systems in the Argentine Pampas. Soil Tillage Res 62:55-60. doi:10.1016/S0167-1987(01)00216-1

Liu H, Probst A, Liao B (2005) Metal contamination of soils and crops affected by the Chenzhou lead/zinc mine spill (Hunan, China). Sci Total Environ 339:153-166. doi:10.1016/j.scitotenv. 2004.07.030

Liu WX, Li HH, Li SR, Wang YW (2006) Heavy metals accumulation of edible vegetables cultivated in agricultural soil in the suburb of Zhengzhou City, People's Republic of China. Bull Environ Contam Toxicol 76:163-170. doi:10.1007/s00128006-0981-3

Liu WX, Shen LF, Liu JW, Wang YW, Li SR (2007) Uptake of toxic heavy metals by rice (Oryza sativa L.) cultivated in the agricultural soil near Zhengzhou City, People's Republic of China. Bull Environ Contam Toxicol 79:209-213. doi:10.1007/ s00128-007-9164-0

Murzaeva SV (2004) Effect of heavy metal on wheat seedlings: activation of antioxidant enzymes. Appl Biochem Microb 40:98103. doi:10.1023/B:ABIM.0000010363.69146.bd

Nan Z, Zhao C, Li J, Chen F, Sun W (2002) Relations between soil properties and selected heavy metal concentrations in spring wheat grown in contaminated soils. Water Air Soil Pollut 133:205-213. doi:10.1023/A:1012962604095

Norra S, Berner ZA, Agarwala P, Wagner F, Chandrasekharam D, Stüben D (2005) Impact of irrigation with As rich groundwater on soil and crops: a geochemical case study in West Bengal Delta Plain, India. Appl Geochem 20:1890-1906. doi:10.1016/ j.apgeochem.2005.04.019

Öncel I, Keles Y, Üstün AS (2000) Interactive effects of temperature and heavy metal stress on the growth and some biochemical compounds in wheat seedlings. Environ Pollut 107:315-320. doi:10.1016/S0269-7491(99)00177-3

Ouzounidou G, Moustakas M, Eleftheriou EP (1997) Physiological and ultrastructural effects of cadmium on wheat (Triticum aestivum L.) leaves. Arch Environ Contam Toxicol 32:154-160. doi:10.1007/s002449900168

Panda SK, Chaudhury I, Khan MH (2003) Heavy metals induce lipid peroxidation and affect antioxidants in wheat leaves. Biologia Plantgum 46:289-294. doi:10.1023/A:1022871131698

Petruzzelli G, Lubrano L, Cervelli S (1987) Heavy metal uptake by wheat seedling grown in fly ash-amended soils. Water Air Soil Pollut 32:389-395. doi:10.1007/BF00225123

Rubio MI, Escrig I, Martínez-Cortina C, López-Benet FJ, Sanz A (1994) Cadmium and nickel accumulation in rice plant. Effects on mineral nutrition and possible interactions of abscisic and gibberellic acids. Plant Growth Regul 14:151-157. doi:10.1007/ BF00025217

Stolt JP, Sneller FEC, Bryngelsson T, Lunborg T, Schat H (2003) Phytochelation and cadmium accumulation in wheat. Environ Exp Bot 49:21-28. doi:10.1016/S0098-8472(02)00045-X

Wong SC, Li XD, Zhang G, Qi SH, Min YS (2002) Heavy metal in the agricultural soils of the Pearl River Delta, South China. Environ Pollut 119:33-44. doi:10.1016/S0269-7491(01)00325-6

Zarcinas BA, Pongsakul P, Mclaughlin MJ, Cozens G (2004) Heavy metal in soils and crops in Southeast Asia. 2. Thailand. Environ Geochem Health 26:359-371. doi:10.1007/s10653-005-4670-7 